This is the accepted manuscript of the article, which has been published in Journal of Youth

Studies. 2018, 21(10), 1344-1360. https://doi.org/10.1080/13676261.2018.1468022

\title{
Under Pressure to Become - from a Student to Entrepreneurial Self
}

\begin{abstract}
This paper discusses how entrepreneurial discourse and the idea of entrepreneurial self are internalized by university students and how they affect their thoughts about education-work transition and their ideas and feelings about their future. The data is gathered by applying visual and narrative methods. It is composed of reflection texts attached to pictures and empathy-based-stories written by students who are about to graduate from BA and MA programs in social sciences, humanities, business and administration at Universities of Tampere (Finland) and Barcelona (Spain). The analysis reveals that university students have internalized the entrepreneurial ethos but not uncritically. They question the economy-based work-oriented entrepreneurial self -

discourse. Work and income are no longer trusted as grounds for good life. Although students wish for a steady income from a permanent job, they are very aware of the erratic reality. Consequently, they aspire after balance between work and life. They emphasize rootedness in a place and physically close social relations as the resources to cope with the uncertainties in the working life and society, and as the most important ingredients of good life. Perhaps the students are in the process of updating the components of good life to better match with the current reality.
\end{abstract}

Keywords: entrepreneurial self, university graduates, transition, working life, future plans, expectations 


\section{Introduction}

Experiences of becoming are strongly influenced by social, political and economic structures and institutions (France 2016, 2). In the current neoliberal context and discourse, (young) people are portrayed as flexible, creative, self-reliant and resilient individual managers of their own lives and careers whose success or failure is up to the level of their entrepreneurial mindset (Brökling 2016). Yet, not much is known how entrepreneurial discourse has actually been internalized, whether it is questioned and how does it affect young peoples' thoughts about education-work transition and ideas about their future. This article seizes on these questions from the viewpoint of university students who are about to graduate from Bachelor's and Master's programmes in social sciences, humanities, business and administration at two European universities.

The article interlinks with the growing line of studies that pay attention to what young people actually think rather than what they do or don't do (see e.g. Atkinson 2010; Cairns, Growiec and de Almeida Alves 2014; Carabelli and Lyon 2016; Di Blasi

et al. 2016; Mononen-Batista Costa and Brunila 2016). The discussion here is based on findings of a research that aims at giving voice to students' own thoughts, concerns and plans concerning their university-work transition and their expectations of and hopes for the future work and life.

Steven Roberts (2011) claims that studies of transition tend to focus either on those who stumble and fall or those who pass the transition with flying colours, and ignore the ordinary young people i.e. 'missing middle'. University students may be perceived as the 'elite' among their peers. Due to their high education (HE), they are 
expected to smoothly take their place in the labour market and succeed in terms of career and income development. It is true that HE graduates are better off in the labour market than those with low levels of education but HE is no longer a guarantee for a stable position in the labour market, for a upward career development and secure income (Brown, Lauder and Ashton 2011; France 2016; Moreau and Leathwood 2007). Today's university graduates are struggling with very different social and economic conditions from previous graduate generations. Although they are the besteducated generation in Europe ever and demographically the age groups are smaller than before, their transition to work life has become more difficult, complex and elongated (Mononen-Batista and Brunila 2016, 21). A growing number of European graduates find it difficult to find employment and especially such jobs that correspond to their studies (Bessant, Farthing and Watts 2017; Cairns, Growiec and de Almeida Alves 2014; Vuorinen-Lampila 2016). The financial crisis (2007-2008) and the economic downturn combined with austerity policies have accelerated this paradoxical development. Yet, in policy actions and discourse, education and especially HE continue to be regarded as the means to ensure and enhance individual's workability and employability, and as a societal remedy for future success in the global markets (Author and Tervonen-Gonçalves forthcoming).

In line with education and labour market policies, policy recommendations and strategies such as the Europe 2020 strategy, education has become an instrument for economic growth and for increasing productivity of work (Moreau and Leathwood 2006; Vuorinen-Lampila 2016). The instrumental value of education seems to override the all-round cultivating value. In a same vein, practices of continuous, life-long learning and self-development has replaced the normative transition from education to work and from youth to adulthood. Paradoxically, self-development does not refer to 
gaining better or deeper understanding or maturity but to skills that are easily salable, marketable and negotiable. What is the value of (higher) education to students' themselves? Is the diploma only a necessary requirement one has to fulfil in order to edge towards the labour market or does it have some other bearing?

The article continues by reviewing the neoliberal discourse and the entrepreneurial ethos. Concepts of entrepreneurial self and entrepreneurial mindset capture the central idea of the ethos and the expectations imposed to (young) people. Thereafter I introduce the data. In the analysis, I concentrate on university students' thoughts and feelings concerning the university-work transition, labour markets and working life, and work-life balance. Finally, I conclude with the discussion on how university students have internalized the entrepreneurial discourse and ethos, how the ethos affects students' ideas of future and their plans after graduation, and how they reflect on it.

\section{The Neoliberal Discourse and Entrepreneurial Self}

The policy actions and policy discourse define young people as a human resource for economic development, as students, consumers, flexible workers (Wyn and Woodman 2006, 504) and, increasingly, as entrepreneurs. The concept of entrepreneurship does not only refer to having a business, but also to certain attitudes, orientations and mindsets that can be thought (Bröckling 2016; France 2016; Mononen-Batista Costa and Brunila 2016; Serrano Pascual and Martín Martín 2017). The desired attributes for individuals are workability, adaptability and mobility. Education and, particularly HE, is regarded as the means to ensure and enhance one's workability and adaptability but HE in itself is not enough. Mobility - learning, working and entrepreneurial mobility- is 
presented as the means to unleash the potential of individuals in Europe (Author and Tervonen-Gonçalves forthcoming).

In the current neoliberal context and discourse, people are portrayed as flexible, creative, self-reliant and resilient individual managers of their own lives and careers whose success or failure is up to the level of their entrepreneurial spirit or mindset. The discourse of entrepreneurial self that is constructed and maintained by policies, strategies and recommendations does not tell (young) people what they are but what they ought to become (Bröckling 2016). Entrepreneurial mindset and all the '(a)bilities' (workability, employability, adaptability, flexibility, mobility) are about futurity (Adkins 2008). That is to say, that what one is expected to do and achieve is more important than what one already is able to do or have done (Nikunen 2016, 3). Thus, self-entrepreneur is never finished or ready. Further education and the need for personal growth becomes continuous and permanent (life-long learning). The need to selfoptimize requires comparisons and comparison entails competition. Due to the constantly changing conditions, a person's position in relation to the other competitors is always temporary. The way to stay in competition is constant self-improvement and self-marketing. Working on self is working on one's work- and employability. Thus, being an entrepreneur is not what you do for living but an attitude to life (Brökling 2016).

The problem with the discourse of entrepreneurial self is that it lose sight of social structures. It naively and simplistically presents the world as if we all were equal agents in free markets, like age, gender, ethnicity or social class have no effect what so ever. Unemployment, social exclusion, misfortune of any kind is your own failure. The reasoning defined by economic and market values form discursive practices in which social cohesion, inclusion and well-being are understood to result from one's 
participation in work life (Mononen-Batista Costa and Brunila 2016.) How this economy-based work oriented entrepreneurial self -discourse effect on university students' thoughts, feelings and views about their university-work transition and their future?

\section{Data, Methods and Analysis}

How to study university students' own thoughts and feelings in the university environment, and by a person belonging to the university staff? How to create an unrestrained atmosphere and how do I, who train students to express themselves according to academic conventions, encourage them to express their feelings and innermost thoughts intuitively and freely, in a non-academic fashion? To overcome these challenges I decided to apply the so-called creative methods. Creative methods are said to enable people to communicate in a meaningful way about their identities and experiences and their own thoughts through creatively making things themselves, and then reflecting upon what they have made (Gauntlett and Holwarth 2006).

As I am interested in students' thoughts and feelings about university-work transition and their views of the future, I gathered the data applying visual methods. According to Gillian Rose (2012), use of pictures facilitate 'mental' moving between past, present and future. Use of pictures help to think and create new ways of seeing and generates new perspectives and questions. First, I asked the students to choose a picture that describes or reflects their thoughts and feelings that finishing studies and moving into work life evokes in them, to title the picture, and to write a short reflection text including information about the origin of the picture (data 1). It is worth noting, that it is 
not the pictures but the reflection texts attached to them that I analyse as data (see Tinkler 2013).

Second, I applied narrative methods and particularly empathy-based-stories to provide students an opportunity to use their own voice and to make their tacit knowledge visible. Empathy-based-stories are short imagined writings composed according to an introductory script provided by the researcher. The stories are possible stories about what may happen and what different things may mean. This method enables collecting contextual and timely bound cultural meanings and perspectives (Posti-Ahokas 2013). I asked students to imagine time three years after graduation when they are in work life and asked them to write a short (1-2 pages) story describing what kind of work they do in what kind of a work place and how their studies benefit them in their work (data 2). Students had two weeks to accomplish these two tasks and then I met them in groups and discussed about the issues that raised from the tasks. I did not record the group discussions but kept a research diary. The whole data analyzed here consist of reflection texts (data 1) and empathy-based-stories (data 2) written by 55 students amounting 86 A4 pages of text.

I collected the two data sets during the academic year 2014-15 at the Universities of Tampere, Finland and of Barcelona, Spain. 19 Master's degree students in social sciences and humanities in Tampere and 27 Bachelor's degree students and 9 Master's degree students in sociology, business and administration in Barcelona took part. In Barcelona, the groups were international having students from Spain but also from all the continents and around Europe. In Tampere, all the students were native Finns. Majority of the students were female in both universities. The average age for MA students was 28 and for BA students 21. The data is multilingual. The reflection texts and empathy-based-stories are written in Finnish, English and Spanish. The group 
discussions were conducted in Finnish and English. Thus, some of the excerpts in the article are my translations from Finnish and Spanish into English. I asked a written permission from each student to use the texts and the pictures that were made or taken by students themselves as a data for research and for academic presentations and publications.

Despite the small size of the data, I find it rich and resonant with feelings, thoughts, ideas and plans. Due to the heterogeneity of the sample, I am not able to make any country, gender, age or discipline based comparisons. Because of this, and in order to guarantee students' anonymity, I do not refer to students' disciplines, their nationality nor whether they were students in Tampere or Barcelona at the time of the data collection. The excerpts are accompanied with the information of students' gender and age (F23 = female age 23, M23 = male age 23). I have analysed the reflection texts and empathy-based-stories inductively by using content analysis to distinguish the recurring themes in the data. Finally, I reflect the findings with discoveries of studies done among graduates and about education-work transition in recent years.

\section{Transition from University to (Work) Life}

Transitions are crossroads or milestones on the path of life, which direct and shape the life course. Transitions are also potential moments for crisis and change (Marin 2001). On one hand, it is a point in life that opens all kinds of possibilities and vistas of the future. On the other hand, it evokes anxieties and concerns. University-work transition is an important point in students' lives and it arouses range of mixed emotions. The picture most often chosen to reflect the feelings connected with the transition is of a cliff. 
[Picture 1 around here]

The rock represents my life as it is now; stable, predictable and with little responsibility. (...) Staying on a rock, however, will not lead to any progression; at some point I am forced to leap into the ocean (...) The ocean represents the working life of which I feel and think of as uncertain, hostile but also as nurturing in the sense that it offers many possibilities for me as a person. (...) (M 23)

Similar picture titled 'Free fall' presents a group of friends holding hands and jumping from a cliff to the sea while the sun is setting in the background. Attached to the picture, a student writes:

Before the scene they were standing together on the edge of the cliff, maybe holding hands. The water in front of them is deep and they don't know what's underneath. The cliff is really comfortable. This is how I experience university- I feel supported and I stand with two feet on the ground...but thinking about the whole application process for a job makes me feel like I am jumping off my safe 
cliff. And I don't question the jump because my friends are with me but in the air I cannot hold their hands, I have to make my own decisions. (F 23)

There were also more tranquil pictures of cliffs and thoughts about transition. In the picture below, the student sits on a ledge looking at the open view over the city up to the sea. According to her, this picture captures perfectly how she feels about finishing up her studies: ‘. .. on top of a mountain with the world of opportunity in front of me'. She continues: 'I am sitting on the background looking at all the beautiful things in front of me, similar to how I feel about finishing college (...) I feel both overwhelmed slightly but also excited as to the many prospects that lie ahead of me in my working career $(\ldots)^{\prime}(\mathrm{F} 21)$

[Picture 2 around here]

School, university, the education system is the 'solid ground' and what is about to follow is a jump to unknown. Student life gives structure and purpose to life. It is described as a relatively carefree time with fairly few responsibilities. As a student, you are surrounded with like-minded people with similar interests and, more or less, at the same life stage. The university and the peers are an important source of the sense of security, but when the time of graduation comes and you should step out into the world of work, you are on your own.

Students in the data expressed a strong belief in higher education. To have the degree is considered as the basic requirement one needs to fulfil when entering the labour market. University degree is also regarded as key to interesting jobs. Education is valued pragmatically and instrumentally because of the importance of educational 
credentials, and because it is considered as the medium to achieve at least some sense of control over the future (see Wyn and Woodman 2006, 508). Yet, majority of the students also emphasised the importance of their studies to their personal growth, to their abilities to understand the world, other people and themselves.

I think that knowledge cannot be valued for its "visible" consequences, I mean, knowledge has an inherent value and thanks to it you are the person you are.' (F19)

\section{Making Choices}

By and large the students are optimistic about their future, content with their studies and believe that their education will support them in their pursuits after graduation. They are not worried about finding employment after graduation. Instead, they worry about making a wrong choice and being blown off from the right career course.

I am not afraid of not getting a job. I am more afraid of not taking the right path at the right time and maybe miss a great change. (F21)

The idea of irreversibility of choices once made causes anxiety particularly among the younger students. This anxiety tends to ease with age and with life experience as the older students in their late 20s and 30s did not express such concerns. However, making choices relying if not merely, at least mainly on yourself is commonly found as a strain but also an opportunity and a source of freedom. Similar to studies conducted for 
example among university students in Finland (Laalo and Heinonen 2016) and UK (Moreau and Leathwood 2007), this data also indicates that the idea of individual responsibility and expectation of self-reliance is well internalized:

I myself face the freedom of choice and I am responsible for the choices I make and that I just have to take that as a challenge and as a big adventure. (F 31)

I am the one responsible for what I am doing in the end and have to deal with that. (F 24).

Most students wrote about self-reliance and individual responsibility quite matter-offactly. They recognise that this is what is expected and try to meet the expectations the best they can. But, there are also those who do not feel so self-confident but try to 'train' themselves to meet the criteria like this 26- year-old female student who writes:

It is important to me, a person who easily underestimate herself, to remember that I do have special know-how and expertise and to try to believe in myself even in a tight spot where my own ideas, wishes or values are questioned. (F 26) Majority of the students in the data are quite confident and believe in their abilities to take charge of their own lives. Some have adopted the 'Me Inc. ethos' (see Brökling 2016) so well that like the dominant discourse, they have lost sight of the surrounding society and the frameworks and conditions that affect in individual's free choices: ‘(...) everything is up to me; where I work, how hard I work and what level of success I would achieve.' (F 21). 
There are also more critical voices pondering how the existing social and economic circumstances and such personal traits as social class, gender and ethnicity effect on individual's chances in work and life (see e.g. Moreau and Leathwood 2006). Like this student, they recognize that in reality everything is not completely up to her:

I see the future full of opportunities but (...) You can try to build a bridge or jump hoping that you'll not get hurt (...) Lucky people jump and they arrive to the place they want, they have a parachute (money). Then there are people like me who have to build their own bridge (e.g. university degree and diplomas). The problem is that in this country the building materials are expensive and resources are lacking. That's why having people you trust and love by your side is useful because they can help you to build the bridge or prevent you from falling. (F 19)

Many emphasise positive attitude as the key. Even if you feel a bit intimidated by the world of work, future and responsibilities, things will work out if you stay positive, about not only yourself but about life in general. Yet optimism and positive attitude should not lead you astride as this 21-year-old female student points out: 'But despite the fact that I try to be optimistic I also try to be realistic because these are hard times for dreamers'.

\section{Do I Find My Place in the Labour Market?}

Students express a strong belief in the value of the university degree in the labour market. All, except one who wish to have chosen a more practical career, are happy with their chosen field of studies and feel that they have learned such skills and gained 
knowledge that will benefit and help them in the working life. However, students are not naïve but recognize that the degree guarantees nothing and the competition among degree holders is tuff in the labour market.

The media, current economic and political discourse and education policies generate a work- and career-centred world where a person's worth is measured by her employability and her capacity and willingness to constantly improve and enhance her tradeable skills, and adjust to continuously changing labour markets (Brökling 2016; Mononen-Batista Costa and Brunila 2016; Moreau and Leathwood 2006). This ethos has not gone unnoticed among the students. The (work)career-centred ethos combined with the other tenet of our time, the individual freedom, arouses preoccupations.

This is the problem of our generation. You can be anything you want so you have to force yourself to create your own personality. It is pretty hard when you don’t know for what. I feel like a jelly: always flexible, not shaped, insecure (...) (F26)

According to the students, it is not a problem to find a job. However, finding a job matching with one's education, and which is interesting, demanding and challenging enough may turn out to be problematic.

I fear of not being able to work with something related to my studies. (F 20)

I wonder if I'll ever get an interesting and permanent job. At the same time I would already like to work somewhere else than at the checkout in a grocery shop (where I am now). (F 25). 
Many university students work while they study, often in jobs that are not related to their studies, like the student in the above quotation. Students have experience of wage work which may contribute to the notion that you are able to get a job, but understandably university graduates who have invested in their education and their employability are not satisfied with just a job. The students provide a long list of attributes for the dream job. It ought to be matching with studies, interesting and challenging enough. It should allow living according to one's values and providing possibilities for personal growth, and as a very important factor, social relations with colleagues and work mates should be good and respectful. Students look for The Job but to figure out what The Job might be is not straightforward as a student writes attached to a picture of Edward Munch's painting The Scream:

Today we are supposed not only to have a job but a job that is at the same time a passion. This pressure blocks any constructive ideas! (F23)

Another common worry has to do with uncertainties in the labour market as a student formulated in the quotation below:

\begin{abstract}
On one hand I dislike the idea that I have to push my life aside because of the work career. On the other hand, I fear that I don't even have an access to stable work career but have to drift in uncertainty where fluctuating periods of unemployment alternate with short project-natured jobs. (M 27).
\end{abstract}

It is a well-known fact that the jobs, even the ones fitting with studies, are most likely temporary, short-term and project-natured. Nevertheless, many hope and dream for open-ended contracts and permanent positions with fixed working hours and an office 
of one's own. When the above quoted student imagines his situation three years after graduation he sees himself working full-time with an open-ended contract as an expert in a public sector. He has his own office and fixed office hours from 8 a.m. to 4 p.m. He continues:

(...) although many of my tasks are project-natured, I am able to leave the work in the office - I am not reading e-mails in my free time. Permanent, stabile job balances the stress and rush at work. (M 27)

The uncertainty that fixed-term, part-time and project-natured jobs create is manifested also in the reflections about the future standard of living. High incomes, big houses, and luxury in their lives are not on the top of the wish list. Instead, students contemplate whether they could earn enough to live ordinary and comfortable life, like: '(...) to be able to live in a studio or one-bedroom apartment, to be able to have a holiday, perhaps abroad once or twice a year and not to count your pennies when doing the groceries.' (F 25)

Students picture the labour market as very competitive and uncertain. To be able to compete with the other degree holders and with those who already are in the labour market requires self-promoting and -marketing. The concern is that in the process you will lose your principles and values as you should sell yourself and your skills in whichever kind of a package the prospective employer requires in any given time. A student describes how working in creative field is 'grotesque' and this grotesqueness influences in one's identity negatively: 
(...) because the jobs you get to do are not what they supposed to be. In other words, the work appears largely to be making funding applications, to foist yourself and to hoard contacts rather than concentrating on the core of the matter that is studying and creating music. (M 30)

Losing yourself and misplacing the focus from the heart of the matter, whatever it is that you work with, is a common concern among the students. Younger students particularly think, perhaps somewhat idealistically, that the solution to this problem would be to start an own enterprise or organization where you can work with the issues important to you and stay true to your values. For others, freelancer spirited students, the uncertainty and the requirements to be flexible, agile and able to package and sell yourself and your skills- 'to invent your own career' as a student put it, do not cause anxiety but rather motivate and inspire.

\begin{abstract}
Work projects will be short. It might be quite weary. Fortunately, I am not on one card. As I am able to play (music), at a pinch I can teach or do gigs! One has to seize an opportunity when it tuggs! Then you feel that you are again on the move towards the familiar unknown! (M33).
\end{abstract}

\title{
Am I Able to Balance between Work and Life?
}

Uncertainty of labour markets is closely related to the ability to balance between work and life, a topic that occupies every students' minds. In her research on female experiences of precarious work and entrepreneurial mindset, Hanna Ikonen (2013, 474) 
points out how achieving the active self-sustained agency demanded by the current labour market requires continuous search for a balance between a living wage, wellbeing and the limits of endurance. This is precisely the preoccupation of the students irrespective of gender. Thus, the dream job for many is not only permanent but also such that facilitates combining work and family/caring duties, like one student writes when imagining her working life three years after graduation:

I have a permanent job with long payed holidays at the same time with children's school holidays and no work in the evenings or nights (...) I have a possibility to work also from home and shorter time as I have children in primary school (...) I have a well-established employer and I don't have to worry about lay-offs or dismissals (...) (F 40)

She is a student who is a mother of small children and she imagines her future in very concrete terms. Most students are younger and without similar parental concerns, but practically all of them are afraid that the world of work will be all-consuming. Alarmingly many dread burnout even before they have actually entered the labour market (see also Aronson, Callahan and Davis 2015; France 2016). Based on the data, one of the biggest challenges in future is to find the balance in life: to be able to acquire and do meaningful, challenging and demanding work while also being able to maintain close social relations and have time for family, a partner and friends, and to have time also for yourself. 
Nowadays most people are living for the work or for the obligations without taking time for themselves, but I don’t want my work to be completely my life. (F 20)

I am torn between my perfectionism of doing a good job and my vision of life of not being a workaholic. (...) I am thinking about establishing my own company but I am a daughter of a workaholic mother - do I really want my kid’s life to be like this? I want to believe that I can do both, but even if it's possible it's going to be stressful - do I want that? (F23)

Although work is important to me I don't want it to be the centre of my life there has to be place also for my partner and other close relationships. (F 23)

Finding balance is about coping with ambitions, and contradicting responsibilities and demands. It is also about having a decent life: work life where people working together respect one another and life where work is a significant but only one part of it. Nearly all students in the data emphasise the importance of good social relations both at work and in private life. Good relations with colleagues at the work place is one of the most important aspects of The Job. Likewise, close relationships with friends and family are the most important elements in balanced life and the source of coping with insecure, demanding and hectic (working) life. Majority of students emphasise how close social relations, frequent face-to-face interaction with family and friends and putting down roots is paramount to individual well-being. Strong emphasis on feel of rootedness and staying put does not fit well with the expectations of being mobile and thus maximising one's employability. Based on this data, moving after a job within a country or between 
countries might be an option in the early stage of the work career and before starting a family. None of the students in this sample plan to build a mobile career and have mobile way of life, not even those who themselves were mobile exchange students at the time of data collection. Instead, they wish that in the future they would to be able to stay put and have 'normal' life.

\section{Conclusions and Discussion}

University-work transition raises thoughts about responsibility and choice. Stepping out from the structured world of education to the world where social structures no longer offer predictable paths for future life evokes anxieties about ones' capabilities to make the individual choices and to be self-reliant. Several studies done in western countries

like Australia, Finland and Spain note increased acceptance of personal responsibility among (young) people (Wyn and Woodman 2006; Laalo and Heinonen 2016; Mononen-Batista Costa and Brunila 2016; Serrano Pascual and Martín Martín 2017). Under the current neoliberal context and discourse promoting the idea of entrepreneurial self, it is reasonable to ponder whether the students have any other options but embrace the idea of being managers of one’s lives (Bröckling 2016). This study indicates that students have acknowledged the expectations and demands of entrepreneurial self. They clearly know that they ought to be workable, adaptable, agile, flexible and mobile. They do believe in higher education and in its worth in the labour market. They have invested in their workability and self-development, and are willing to continue to do so but they wish they could do it in their own terms. In other words, students hope for strong agency. 
Although majority of the students are quite positive about their future prospects in working life, they realise that their work careers will most likely be composed of fixed-term jobs, assignments and projects. Nevertheless, they hope to maintain steady income regardless of changing assignments and projects. As the labour markets are in a state of flux, staying in the markets requires constant promotion of yourself and your ability-package. This is also an internalised state of affairs but what most students hope for is the ability to decide themselves what abilities to sell, how and to whom instead of converting oneself into a package determined by the needs and values of fluid markets and varying employers.

The most criticised ability is mobility. Life as an expert-nomad who creates her working career following the job opportunities around the European Union or world does not seem to attract students. Working abroad would be an option for some in the early stage of the work career. For others moving abroad after a job appears as a very probable necessity in near future. As a study among Portuguese tertiary-educated youth indicates, moving abroad is an important and sometimes the only option to look for a job and decent livelihood but there is no sign of a major youth exodus (Cairns, Growiec and de Almeida Alves 2014, 1057). Cairns and others claim that even in the crisis-hit European societies like Portugal, Spain and Ireland, thinking about moving abroad is a form of escapism rather than a realistic option (Cairns, Growiec and Smyth 2012).

Mobility is not only about personal choices or a necessary way to make a living. Just like the idea of entrepreneurial self, demand of educational and career mobility is based on the delusive idea of equality. However, not everybody has the same chances to be mobile, as Beverly Skeggs (2004) points out. Those with financial means can leave and move around if they so wish. Thus, whether being mobile or staying put, and whether to be mobile out of free will or of necessity is also a question of social class. 
Although students do not explicitly bring forth the class perspective, some ponder connections between opportunities and constraints stemming from social, family or local backgrounds. None of the students in this study planned for mobile life-style and the main argument against it was not background but the conviction that continual mobility is detrimental for the individual well-being and for attaining balance in life both highly valued aspects in life.

In face of uncertainty and change, putting down roots, staying put and being close to those important to you become important aspects in life. Just like for the Australian young people in the study of Johanna Wyn and Dan Woodman (2006), social relationships play a very important mediating role in building a life, achieving wellbeing and finding the balance also for the students in this data. Good and respectful relationships both in private life and in working life are seen as the most important resources to cope with uncertainty. Trusted others provide material and most of all immaterial (emotional, social and cultural) resources to succeed in life. What is especially emphasised in connection to social relationships is the importance of physical closeness with the important people be they family, a partner, friends or colleagues. Staying in touch via Skype and other ways provided by the modern communication technology does not suffice. Physical closeness and ability to communicate face to face requires staying put. Descriptive of this is how the students talk about roots and emphasise how important it is for personal well-being to have the feel of belonging to a place and to its people.

Research (e.g. Aronson, Callahan and Davis 2015; Wyn and Woodman 2006) has shown how young people prioritize achieving a balance in their lives and this study is no exception. The biggest concern among the students is whether they are able to find balance between work life and private life and to have time also for themselves. This 
concern is very much related to the nature of contemporary work. Young people like the university students here have accepted, more or less willingly, that they will have many jobs and probably several occupations during their lifetime. They know that even the employment fitting with their studies is most likely precarious (see Wyn and Woodman 2006). As they have invested in their work- and employabilities, they consider work as an important aspect of their lives not only financially but also personally. Yet, work is not regarded as a reliable basis for meaningful life. Consequently, the students in this study criticise the extremely work-oriented ethos of our times and emphasize the permanence of place and people.

What the university students have set their sights on is balanced, 'ordinary' life where rewarding and interesting work and relatively steady and sufficient income is combined with rich and physically close social and private life. Is this a realistic aim for the future or is this a mere fantasy of the good life?

Lauren Berlant (2011) claims that our ideas of good life are no longer sustainable and attainable in the present. According to her, the idea of good life that we so eagerly cling to is related to upward mobility, job security, political and social equality and durable intimacy, the criteria we should meet in order to make up a meaningful life in capitalist-liberal societies. Yet, at the same time, society can no longer provide us opportunities to fully meet these criteria.

The economic idea that assumes a clear connection between investment in human capital (education) and life-long economic awards in the form of secure employment, high incomes and possible upward social mobility has stood for half a century and achieved a ‘common-sense’ status (Bessant, Farthing and Watts 2017, 8990). The university students have bought the human capital model as they have invested heavily on their education and they express a strong belief in the value of their high 
education and diplomas in the labour market. Yet, they are also aware that the human capital model no longer works in a way it used to. They know that their university degree guarantees nothing. They do not really dear to expect to get a permanent, secure job and steady, not mention, high income. Yet, the awareness of the reality does not prevent them from hoping. According to Berlant (2011), this discrepancy is an example of cruel optimism that occurs when we desire or promote something that actually prevents us to flourish. Does hoping prevent these students from flourishing? The students see themselves and their peers in a more complex way than they are often given credit for (see Bessant, Farthing and Watts 2017, 125-143) and they are not naïve. So, instead of living in a state of cruel optimism, perhaps they are in fact redefining the criteria for good life, criteria that is better fitting with the current reality.

\section{References}

Aronson, Pamela, Callahan, Thomas and Davis, Timothy. 2015. "The Transition from College to Work During the Great Recession: Employment, Financial, and Identity Challenges”. Journal of Youth Studies 18 (9): 1097-1118. DOI:

10.1080/13676261.2015.1020931. 
Berlant, Laura. 2011. Cruel Optimism. Durham and London: Duke University Press.

Bessant, Judith, Farthing, Rys and Watts, Rob. 2017. The Precarious Generation. A

Political Economy of Young People. Abingdon: Routledge.

Brown, Phillip, Lauder Hugh and David Ashton. 2011. The Global Auction. The Broken

Promises of Education, Jobs, and Incomes. Oxford: Oxford University Press.

Brökling Ulirch. 2016. The Entrepreneurial Self. Fabricating a New Type of Subject.

(Translated by Steven Black). London: Sage.

Cairns, David, Groweic, Katarzyna and de Almeida Alves, Nuno. 2014. “Another

'Missing Middle’? The Marginalized Majority of Tertiary-educated Youth in Portugal

During the Economic Crisis”. Journal of Youth Studies 17 (8): 1046-1060. DOI:

10.1080/13676261.2013.878789.

Cairns, David, Groweic, Katarzyna and Smyth, Jim. 2012. "Spatial Reflexivity and Undergraduate Transitions in the Republic of Ireland after the Celtic Tiger.” Journal of Youth Studies 15 (7): 841-857.

France, Alan. 2016. Understanding Youth in the Global Economic Crisis. Bristol:

Policy Press. 
Gauntlett, David and Holzwarth, Peter. 2006. “Creative and Visual Methods for

Exploring Identities”. Visual Studies 21 (0): 82-91. DOI: 10.1080/14725860600613261.

Ikonen, Hanna-Mari. 2013. "Precarious Work, Entrepreneurial Mindset and Sense of Place: Female Strategies in Insecure Labour Markets”. Global Discourse 3 (3-4): 467481. DOI: $10.1080 / 23269995.2013 .864085$.

Kelly, Peter. 2006. “The Entrepreneurial Self and 'Youth at-risk': Exploring the Horizons of Identity in the Twenty-first Century”. Journal of Youth Studies 9 (1): 17-31, DOI: $10.1080 / 13676260500523606$.

Laalo, Hanna and Heinonen, Jarna. 2016.”Governing the Entrepreneurial Mindset:

Business Students’ Constructions of Entrepreneurial Subjectivity”. European

Educational Research Journal 1-18. DOI: 10.1177/1474904116662288.

Marin, Marjatta. 2001.’Tarkastelukulmia ikään ja ikääntymiseen (Perspectives on age and ageing)”, in Lapsuudesta vanhuuteen. Iän sosiologiaa (From childhood to adulthood. Sociology of age), edited by Anne Sankari and Jyrki Jyrkämä, 17-48. Tampere: Vastapaino.

Mreau, Marie-Pierre and Leathwood, Carole.2007. “Graduates' Employment and the Discourse of Employability: A Critical Analysis”. Journal of Education and Work 19 (4): 305-324. DOI: 10.1080/13639080600867083. 
Mononen-Batista Costa, Sari and Brunila, Kristiina. 2016. “Becoming Entrepreneurial: Transitions and Education of Unemployed Youth”. Power and Education 8 (1): 19-34. DOI: $10.1177 / 1757743815624115$.

Nikunen, Minna. 2016. "Young People, Future Hopes and Concerns in Finland and the European Union: Classed and Gendered Expectations in Policy Documents”. Journal of Youth Studies. DOI: 10.1080/13676261.2016.1260693.

Author and Tervonen-Gonçalves, Leena. Forthcoming 2017. ”Reproducing or remaking the social contract with young people in Europe 2020 Strategy?”. In Economy, Society and Coordination in the Policy Design of the EU. An Empire of Shopkeepers in the Making? edited by Risto Heiskala and Jari Aro. Houndmills Basingstoke: Palgrave MacMillan.

Pongratz, Hans J. and Voß, Günter G. 2003. “From Employee to ‘Entreployee’. Towards a 'Self-entrepreneurial’ Work Force?”. Concepts and Transformation 8(3): 239-254.

Posti-Ahokas, Hanna. 2013. "Empathy-based Stories Capturing the Voice of Female Secondary School Students in Tanzania”. International Journal of Qualitative Studies in Education 26 (10): 1277-1292. DOI: 10.1080/09518398.2012.731533

Roberts, Steven. 2011. “Beyond 'NEET’ and 'Tidy’ Pathways: Considering the 'Missing Middle’ of Youth Transition Studies”. Journal of Youth Studies 14 (1): 21-39. 
Rose, Gillian. 2012. Visual Methodologies. An Introduction to Researching with Visual Materials. $3^{\text {rd }}$ Edition. London: Sage.

Serrano Pascual, Amparo and Martín Martín, Paz. 2017. “From 'Employab-ility to 'Entrepreneurial-ity' in Spain: Youth in the Spotlight in Times of Crisis”. Journal of Youth Studies 20 (7): 798-821. DOI: 10.1080/13676261.2016.1273513.

Skeggs, Beverly. 2004. Class, Self, Culture. London: Routledge.

Tinkler, Penny. 2013. Using Photographs in Social and Historical Research. London: Sage.

\author{
Vuorinen-Lampila, Päivi. 2016. “Gender Segregation in the Employment of Higher \\ Education Graduates”. Journal of Education and Work 29 (3): 284-3018. DOI: \\ 10.1080/13639080.2014.934788.
}

Wyn, Johanna and Woodman, Dan. 2006. “Generation, Youth and Social Change in Australia”. Journal of Youth Studies 9 (5): 495-514. DOI:

$10.1080 / 13676260600805713$. 
Picture 1. Make the jump

Student's permission to use his picture in an academic publication.

Picture 2. What lies ahead

Student's permission to use her picture in an academic publication. 


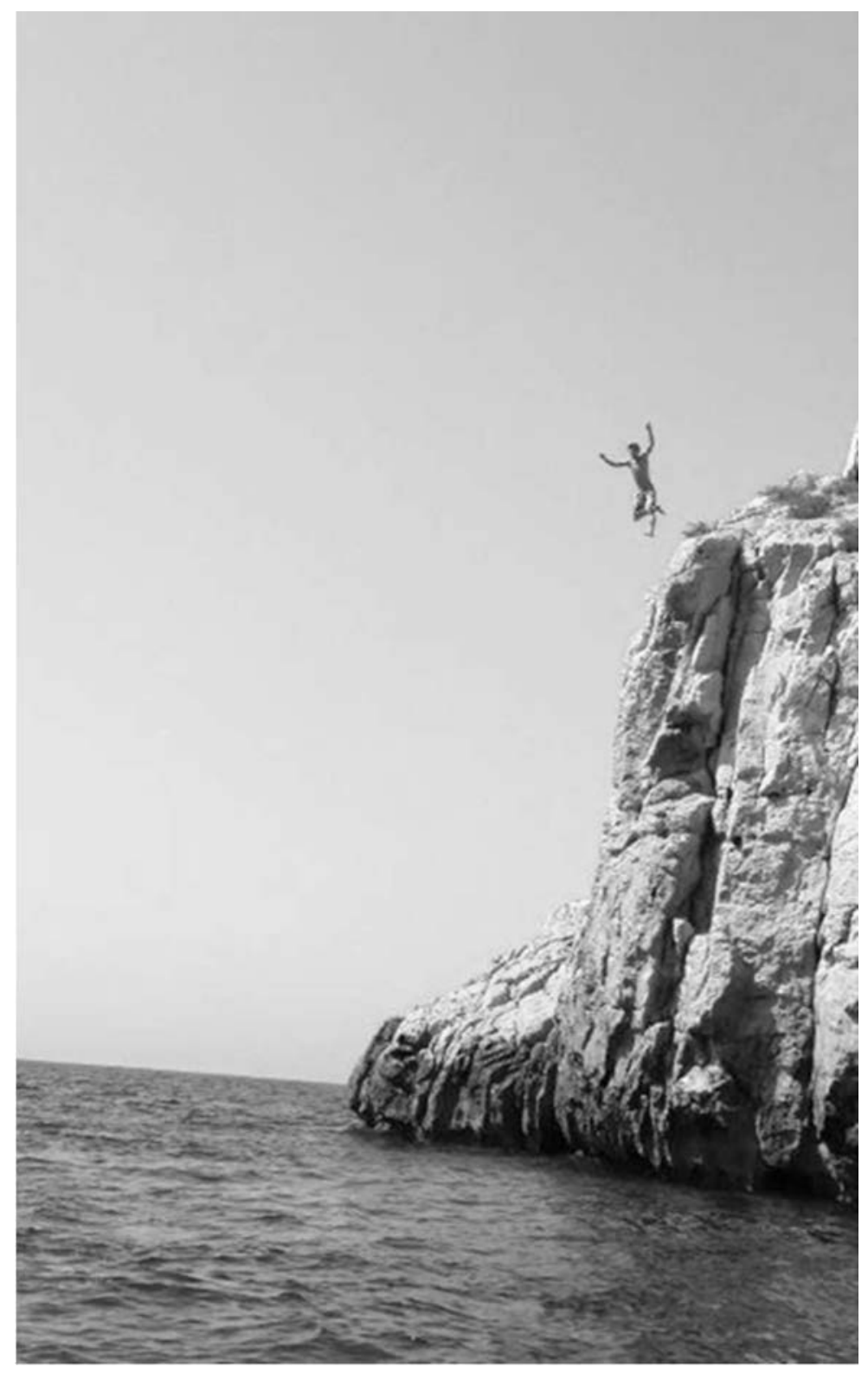

Making the jump

$71 \times 114 \mathrm{~mm}(150 \times 150 \mathrm{DPI})$ 


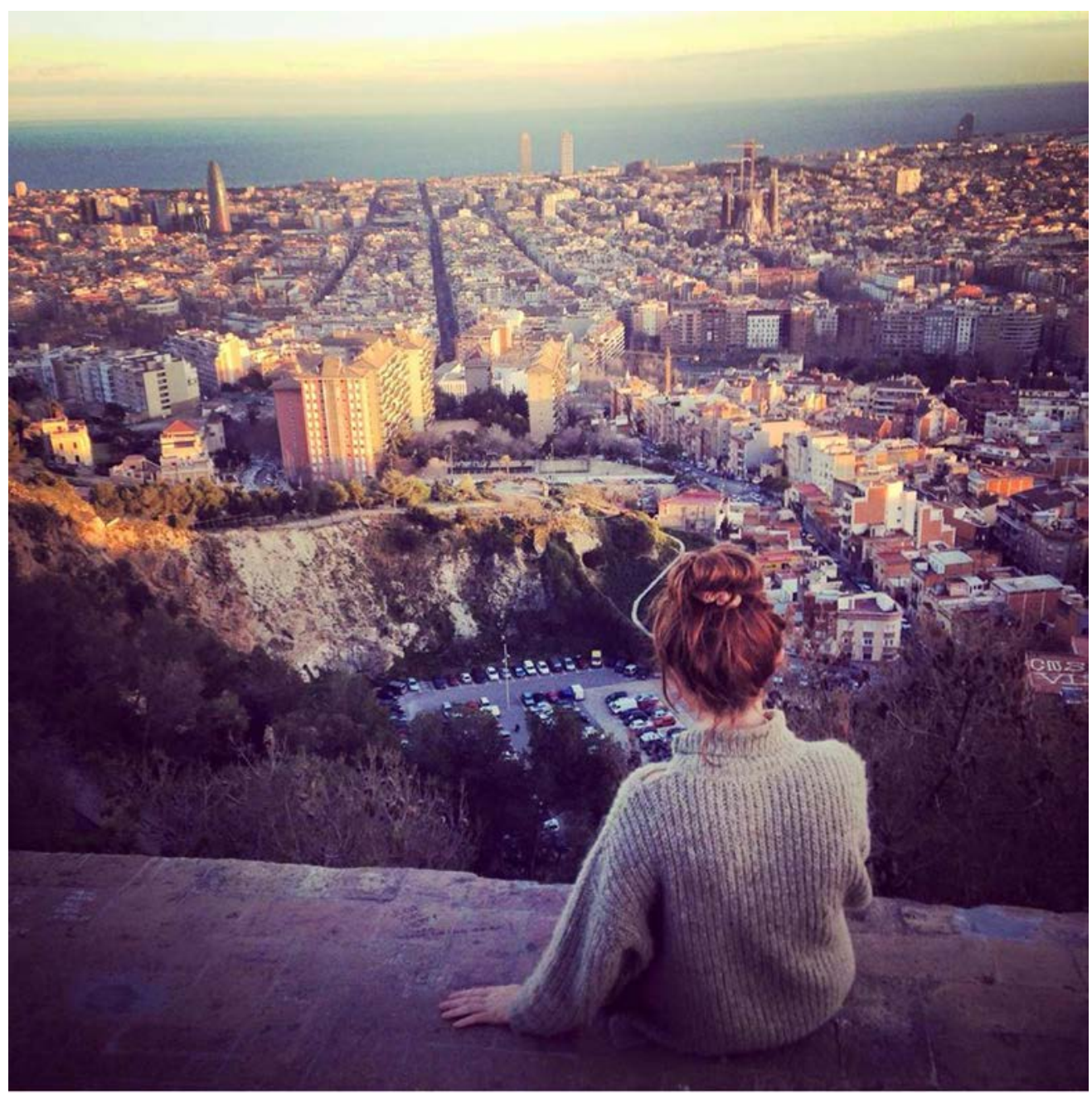

What lies ahead

$338 \times 338 \mathrm{~mm}(72 \times 72 \mathrm{DPI})$ 